\title{
Adsorption Study of Cadmium Ions on Kaolinite Modified by Histidine and Cysteine
}

\author{
NATA ̌́ N N. MLADENOVIĆ, University of Belgrade, \\ Faculty of Technology and Metallurgy, Belgrade \\ MARIJA M. IVANOVIĆ, University of Belgrade, Belgrade, \\ Vinča Institute of Nuclear Sciences, \\ Laboratory for Materials Sciences, Belgrade \\ LJILJANA M. KLJAJEVIĆ, University of Belgrade, Belgrade, \\ Vinča Institute of Nuclear Sciences, \\ Laboratory for Materials Sciences, Belgrade \\ JELENA J. GULICOVSKI, University of Belgrade, Belgrade, \\ Vinča Institute of Nuclear Sciences, \\ Laboratory for Materials Sciences, Belgrade \\ SNEŽANA S. NENADOVIĆ, University of Belgrade, Belgrade, \\ Vinča Institute of Nuclear Sciences, \\ Laboratory for Materials Sciences, Belgrade \\ KATARINA V. TRIVUNAC University of Belgrade, \\ Faculty of Technology and Metallurgy, Belgrade
}

Continuous development of new technologies leads to increasing pollution of water, thus creating the need for new materials that could be used in the processes of its purification. Therefore, adsorbents prepared from agricultural waste, resins, silica gels, zeolites, clays, flying ash, aluminosilicates and other materials are being investigated as potential sorbents. Recently, research has focused on improving the adsorption capacity by modifying the material by binding or impregnating inorganic and organic molecules on the surface. In this paper, the kaolinite modification with amino acids, histidine and cysteine, was performed to improve the efficiency of adsorption of cadmium ion. Cation exchange capacity (CEC) of raw and modified kaolinite was determined by titration with methylene blue. The influence of operating parameters, such as adsorption time, $\mathrm{pH}$ value of the solution, initial metal concentration and temperature, on the capacity and adsorption efficiency were examined. Better agreement of experimental results with Freundlich's adsorption isotherm and the pseudo-second order kinetics model suggest that the adsorption of cadmium ions on the investigated adsorbents takes place by chemisorption mechanism. The change of Gibbs free energy has a negative value for both adsorbents, which shows that the adsorption process is spontaneous. The efficacy of cadmium removal from the aqueous solution onto histidine-modified kaolinite increased from 78.6\% to 91.8\%.

Key words: adsorption, cadmium, amino acids, cation exchange capacity, kaolinite

\section{INTRODUCTION}

Heavy metals are a source of great concern because of their possible reactivity, toxicity and mobility in water and soil. Heavy metals are classified as human

Author's address: Nataša Mladenović, University of Belgrade, Faculty of Technology and Metallurgy, Belgrade, Karnegijeva 4

e-mail: natasa3009@yahoo.com

Paper received: 15.01.2019.

Paper accepted: 12.02.2019. carcinogens according to the International Agency for Research on Cancer. Cadmium, Cd, as highly toxic and cancerogenic heavy metal represents a significant environmental pollutant owing to its potential release during industrial use, mining, and waste disposal. Unlike many organic pollutants, cadmium is constantly accumulated in the environment and cannot be degraded [1].

Several techniques, like ion exchange, reverse osmosis, electrochemical treatment, membrane filtration, etc, have been used to remove heavy metals. Among 
them, the adsorption process is a very suitable technique, due to its simplicity, efficiency and effectiveness as well as lower costs compared to other techniques [2]. Adsorption process includes separation of substance from one phase and its accumulation to another surface [3].

Various adsorbents are used for adsorption of heavy metals from wastewater. Clays are excellent adsorbent materials, because they have a large specific surface area, chemical and mechanical stability, high cation exchange capacity, etc. [4, 5, 6]. Considering cation exchange properties and layered structure of clay materials, it is possible to introduce molecules of other compounds, which can be used to change and tailor their properties. Different guest molecules can be introduced between layers of the clay, depending on the desired result. Because of swelling properties of clays, exchanged molecules can be bigger than original ones, what is compensated by expanse of interlayer spacing in the clay structure [7-9]. Kaolinite, a typical 1:1 type clay mineral composed of $\mathrm{SiO} 4$ tetrahedral and $\mathrm{AlO} 4(\mathrm{OH}) 2$ octahedral sheets, has asymmetric interlayer environments between the layers, i.e. shares a common plane of oxygen atoms and repeating layers of the mineral treatment [20], amino acid modified [5], etc.

Clay minerals can be substantially modified by replacing the natural inorganic interlayer cations with selected organic cations. Organoclays have been heavily explored in numerous scientific and medical fields, due to the accessibility $[2,10]$. Also, it possesses a high chemical stability, cation exchange capacity and low expansion coefficient. Cation exchange capacity, $\mathrm{CEC}$, is the concentration of exchangeable cations on clay material. The cation can be exchanged when brought into contact with other ions in aqueous solution $[11,12]$.

The capacity of the cation exchange is a quantitative measure of the ability of clay mineral to change cation and is expressed in mmol M+/100 $\mathrm{g}$ of dry clay. Average values of CEC for kaolin based on literature is 3-15 meq/100g [12-14]. Increased cation exchange capacity can be achieved by modifying kaolinite. Modification of kaolinite can be done in different ways, e.g. modified with phosphates [12], organic-modifications of kaolinite [16-19], thermal of natural clay minerals and their ability to incorporate a large variety of functional molecules [8, 21, 22]. Amino acids can be considered great modification agents as being one of the main building blocks of living organisms, ecofriendly not causing contamination when released to the environment and having affinity to heavy metal ions.

In this paper, the comparison of effectiveness of kaolinite and kaolinite modified with amino acids, histidine and cysteine, was investigated in the process of adsorption of cadmium ions from aqueous solution. The choice of cysteine and histidine was made in order to determine the influence of additional functional groups in amino acids on adsorption and modification processes. Histidine (C6H9N3O2) has additional basic amino groups and it is expected that side chains exhibit enhanced adsorption properties and interact with clay mainly through the imidazole group [11]. Histidine has three amino groups that can potentially present additional binding sites for $\mathrm{Cd}$ ions from wastewater. $\mathrm{Cy}-$ steine $(\mathrm{C} 3 \mathrm{H} 7 \mathrm{NO} 2 \mathrm{~S})$ has thiol group which has a high affinity for heavy metals [23] and plays a vital role in the synthesis of peptides and proteins and in the detoxification of heavy metals such as cadmium and mercury in living organisms [24-26].

\section{EXPERIMENTAL}

\subsection{Materials and Methods}

The kaolinite clay from Rudovci, Lazarevac, Serbia, was used as an adsorbent in this study. The surface of kaolinite clay was modified by two amino acids, histidine (Roth) and cysteine (Merck).

Fifteen grams of kaolinite clay interacted for $24 \mathrm{~h}$, at room temperature, with $100 \mathrm{~mL}$ of a solution containing $1.55 \mathrm{~g}$ of histidine and $1.21 \mathrm{~g}$ of cysteine. The synthesized adsorbents were washed with de-ionized water, to remove unreacted histidine and cysteine. The presence of amino acids in the filtrate was determined by ninhydrin reaction. After that, the adsorbents were dried at $110^{\circ} \mathrm{C}$. Prepared adsorbents are designated as $\mathrm{K}-\mathrm{HIS}$ and K-CIS and raw kaolinite as K, the appearance of which is shown in Figure 1.

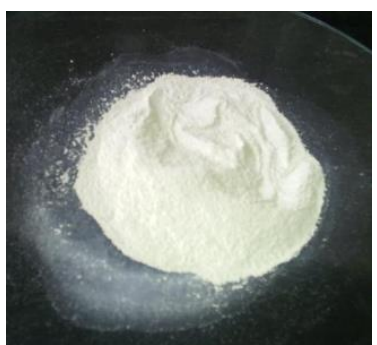

a)

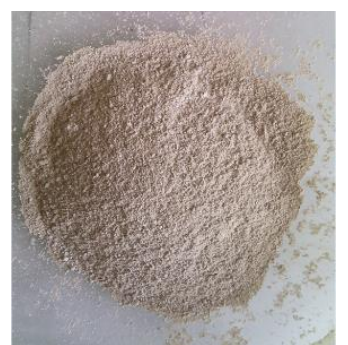

b)

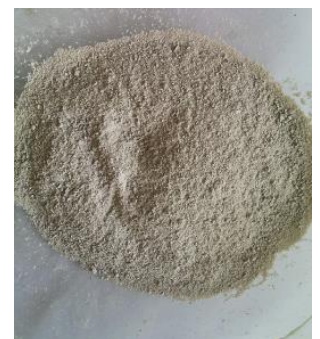

c)

Figure 1 - Adsorbents a) $K, b) K-H I S, c) K-C I S$ 


\section{RESULTS AND DISCUSSION}

Amino acids in water solutions dissociate and turn into ions. Depending on the $\mathrm{pH}$ applied, they can be present in the form of cations, anions or zwitterions. They are adsorbed to kaolinite by exchange with exchangeable ions present in interlayer space of clay. The mechanism of bonding between clay material and amino acid molecules is also not known yet. It can proceed through formation of a chemical bond or electrostatic forces [28].

\subsection{Cation exchange capacity (CEC)}

All clay minerals are inorganic ion exchangers and have ability to exchange cations to a smaller or larger amount. The amounts of amino acid adsorbed and bound are dependent on the type of amino acid, the type of clay, the type of cation predominant on the clays and the basicity or the additional function moiety (e.g. carboxyl, thiol, guanido) of the amino acid [29]. The adsorption of an organic material onto a negatively charged surface is a complex process involving both cation exchange and hydrophobic bonding. In this wo$\mathrm{rk}$, for the determination of cation exchange capacity a methylene blue method was used. The value of cation exchange capacity (presented in Table 1.) for kaolinite used in this work is $18,5 \mathrm{mmol} \mathrm{M}+/ 100 \mathrm{~g}$ clays. The CEC of kaolinite depends on the particle size (both thickness and diameter in the (001 plane) and $\mathrm{pH}$ value. Particle size is more important than crystallinity in affecting kaolinite CEC [30]. For kaolinite modified with histidine, values of CEC decrease slightly, but CEC values of K-CIS are the same as CEC values of kaolinite. For better understanding of the obtained results of CEC values, it is necessary to study the structure analysis of these complex systems of modified kaolinite with amino acids. One of the explanations of obtained results could be that when kaolinite is modified by cysteine, there are no intercalation and occupation of certain reactive positions in kaolinite, so the CEC values remain approximately the same. Cysteine has three disociable protons, and the completely anionic form of cysteine is obtained only in very basic solutions [29]. The interaction mechanism of clay with cysteine in an aqueous medium mostly occurs by weak interactions like van der Waals interactions, hydrogen bonding, dipole-dipole interactions, and other electrostatic forces. Adsorption of the cysteine can be affected by the composition of clay. Oxidation of cysteine to cystine can occur in the presence of iron oxide, whereby the thiol group (-SH) change in the disulfide bond (S-S) occurs [31]. Although the CEC value obtained for histidine-modified kaolinite is lower than the CEC of kaolinite, it potentially contains more sites for binding $\mathrm{Cd}$ ions. The results obtained by Fernandes, 2015 [8] confirmed the incorporation of L-histidine in the structure of the clays. L-histidine having additional basic amino group's side chains is expected to show enhanced adsorption properties [32]. In general, positively charged basic amino acids are more strongly adsorbed than neutral or acidic amino acids, due to ionexchange reactions onto negatively charged clay surfaces [33].

Table 1. Cation exchange capacity for $K, K$-HIS and $K$ CIS

\begin{tabular}{|l|l|}
\hline Adsorbent & CEC, $\mathrm{mmol} \mathrm{M}^{+} / 100 \mathrm{~g}$ \\
\hline $\mathrm{K}$ & 18.5 \\
\hline $\mathrm{K}-\mathrm{HIS}$ & 15.0 \\
\hline K-CIS & 18.6 \\
\hline
\end{tabular}

\subsection{Batch adsorption test}

Data obtained from batch adsorption test were used to calculate the adsorption capacity of metal ion adsorbed on the adsorbent qe, $\mathrm{mg} / \mathrm{g}$, using following mass balance equation (1):

$$
q_{e}=\frac{\left(c_{0}-c_{e}\right) V}{m}
$$

The removal efficiency (R) can be calculated by the following equation (2):

$$
R=\frac{\left(c_{0}-c_{e}\right)}{c_{0}} \cdot 100
$$

where the $\mathrm{c} 0$ and ce (mg l-1) are the initial and the final concentration of $\mathrm{Cd}(\mathrm{II})$ in the solution, respectively.

\subsubsection{Effect of contact time}

Figure 2 shows the change of the adsorption capacity of adsorption of $\mathrm{Cd}$ (II) ions as a function of contact time.

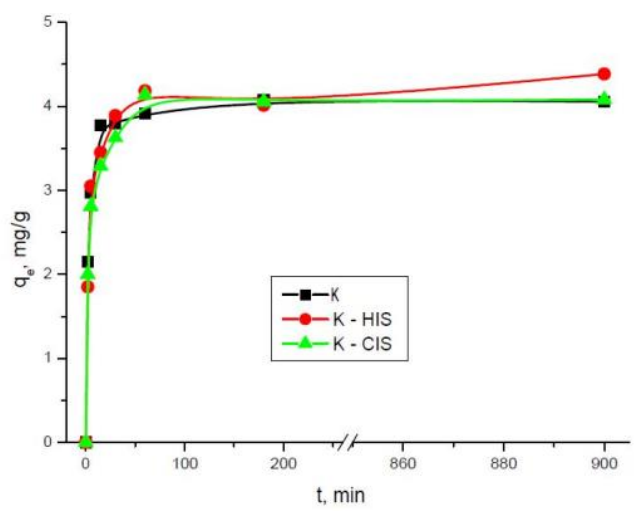

Figure 2 - Influence of contact time on adsorption capacity clays samples $(\mathrm{c} 0=50.0 \mathrm{mg} / \mathrm{dm} 3$, $p H=6.4, T=298 K$ )

The results showed that the equilibrium is reached after contact time of 60 minutes for all adsorbents. There is a large number of active sites for adsorption of cadmium ions present in a high concentration 
solution on the surface of kaolinite, kaolinite modified with histidine and cysteine. After 180 minutes, the adsorption becomes almost constant.

Adsorption was tested in the batch system without additional $\mathrm{pH}$ adjustment $(\mathrm{pH}=6.4)$. This value is in the range in which the maximum adsorption is recorded, as detailed in the following section.

\subsubsection{Effect of $p H$}

The adsorption capacity of the K, K-HIS, K-CIS adsorbents for $\mathrm{Cd}$ (II) ions at various $\mathrm{pH}$ conditions is expressed in Figure 3. The initial $\mathrm{pH}$ range of 3-7.0 was used to study the effect of $\mathrm{pH}$ of the solution on removing Cd (II) by kaolinite and modified kaolinite. The maximum of the adsorption capacity was achieved at $\mathrm{pH}=5.0$ for kaolinite, and $\mathrm{pH}$ values between 6.0 and 7.0 for modified adsorbents. The structure of amino acids depends on the $\mathrm{pH}$ value. In the neutral environment, amino acids have both positive and negative charge, and can participate in the binding of heavy metal ions thus increasing adsorption capacity. $\mathrm{pH}$ values above 7.0 were avoided because of the possibility of metal hydroxide formation and precipitation.

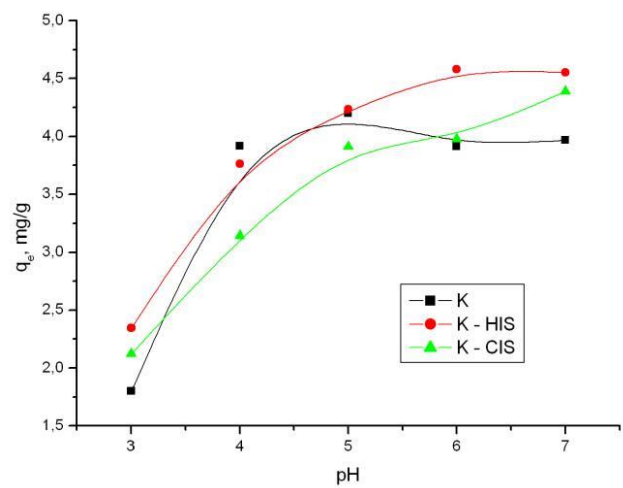

Figure 3 - Influence of $\mathrm{pH}$ on adsorption capacity of clay samples $(\mathrm{c} O=50.0 \mathrm{mg} / \mathrm{dm} 3, t=60 \mathrm{~min}$, $T=298 K$ )

In the literature, the formation of the complex $\mathrm{Cd}$ with cysteine [34] and then its adsorption on kaolinite was reported by Benincasa et al. [35]. However, by changing the order, i.e. the modification of kaolinite with cysteine and then the $\mathrm{Cd}$ ion adsorption similar results are not obtained. Adsorption of $\mathrm{Cd}$ ions takes place through both negative positions on intercalation ions of histidine and on free negative sites of kaolinite, which increases the adsorption capacity of K-HIS.

\subsubsection{Effect of initial concentration of Cd (II) solutions}

Figure 4 shows effects of initial concentrations of cadmium on adsorption capacity onto K, K-HIS and KCIS samples. With the increase of the initial concentration, the adsorption capacity increases linearly, but the efficiency of adsorption decreases with the increase of initial concentration. This suggests that the amount of $\mathrm{Cd}$ (II) adsorption in the examined samples is dependent upon the availability of binding sites for cadmium.

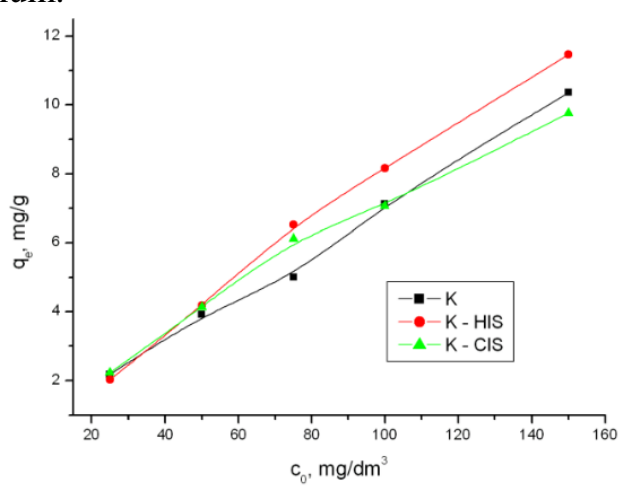

Figure 4 - Influence of initial concentration on adsorption capacity of clay samples $(t=60 \mathrm{~min}$, pH=6.4, $T=298 K$ )

\subsubsection{Effect of temperature}

Figure 5 shows the influence of temperature on the investigated clay samples. At temperature interval from 298 to $313 \mathrm{~K}$ the adsorption capacity for all samples increased. The increase in the adsorption capacity of clay with the rise of temperature may be attributed to the increase in the mobility of metal cations [36] A steep drop in the adsorption capacity at temperatures above $313 \mathrm{~K}$ indicates the start of desorption process.

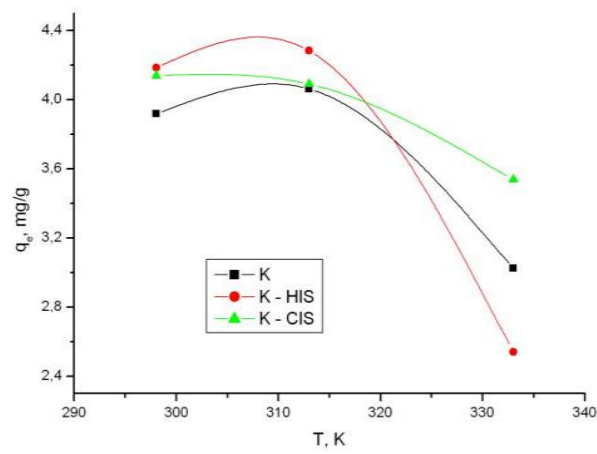

Figure 5 - Influence of temperature on adsorption capacity of clay samples $(\mathrm{c} 0=50.0 \mathrm{mg} / \mathrm{dm} 3, t=60$ $\min , \mathrm{pH}=6.4$ )

\subsection{Adsorption isotherms}

To identify the mechanism of the adsorption process, Langmuir and Freundlich isotherm models were used to fit experimental data.

The Langmuir model was originally developed assuming monolayer adsorption on a surface of the adsorbent with a finite number of adsorption sites. The linear form of the Langmuir equation is represented by equation (3):

$$
\frac{c_{e}}{q_{e}}=\frac{1}{q_{m} K_{L}}+\frac{c_{e}}{q_{m}}
$$


The Freundlich model assumes that adsorption takes place on heterogeneous surfaces of the adsorbent. The linear form of the Freundlich equation is represented by equation (4):

$$
\log q_{e}=\log K_{f}+\frac{1}{n} \log c_{e}
$$

Langmuir and Freundlich constant values and the correlation coefficients obtained after processing the experimental data using equations (3) and (4) are shown in Table 2.

Table 2. Adsorption isotherms parameters for Langmuir and Freundlich models

\begin{tabular}{|l|l|l|l|l|l|l|}
\hline \multirow{2}{*}{ Adsorbent } & \multicolumn{2}{l|}{ The Langmuir model } & \multicolumn{4}{l}{ The Freundlich model } \\
\cline { 2 - 7 } & $K_{L}, \mathrm{dm}^{3} / \mathrm{mg}$ & $q_{m}, \mathrm{mg} / \mathrm{g}$ & $\mathrm{R}^{2}$ & $K_{f}$ & $n$ & $\mathrm{R}^{2}$ \\
\hline $\mathrm{K}$ & 0.080 & 10.69 & 0.72 & 1.03 & 1.77 & 0.98 \\
\hline $\mathrm{K}-\mathrm{HIS}$ & 0.061 & 15.78 & 0.59 & 0.93 & 1.37 & 0.94 \\
\hline $\mathrm{K}-\mathrm{CIS}$ & 0.120 & 10.53 & 0.92 & 1.18 & 1.79 & 0.98 \\
\hline
\end{tabular}

High correlation coefficient values, close to 1 , indicate that adsorption of cadmium ion can be represented by the Freundlich adsorption model and by type it is the chemisorption.

\subsection{Adsorption kinetics}

The kinetics of cadmium (II) ion adsorption on investigated adsorbents was analyzed by linearized pseudo - first and pseudo - second order kinetic models. Pseudo-first order kinetic models can be well described at the beginning of adsorption process. The pseudo-first order equation describes adsorption in solid-liquid systems based on the sorption capacity of solids. The pseudo first order reaction model [36] is expressed as the following equation (5):

$$
\log \left(q_{e}-q_{t}\right)=\log q_{e}-\frac{k_{1}}{2,303} t
$$

The pseudo-second model [20] is based on the assumption of chemisorption of the adsorbate on the adsorbent. This model is expressed as (6):

$$
\frac{t}{q_{t}}=\frac{1}{k_{2} q_{e}^{2}}+\frac{t}{q_{e}}
$$

Calculated values of kinetic parameters are presented in Table 3. High correlation coefficient values, close to 1 , indicate that cadmium ion adsorption kinetics can be represented by the equation of the pseudosecond order and by type it is the chemisorption.

Table 3. Adsorption kinetic parameter of pseudo-first and pseudo-second order

\begin{tabular}{|l|l|l|l|l|l|l|}
\hline \multirow{2}{*}{ Adsorbent } & \multicolumn{2}{l}{ The pseudo-first order } & \multicolumn{2}{l|}{ The pseudo-second order } \\
\cline { 2 - 7 } & $\mathrm{k}_{1}, 1 / \mathrm{min}$ & $\mathrm{q}, \mathrm{mg} / \mathrm{g}$ & $\mathrm{R}^{2}$ & $\mathrm{k}, \mathrm{g} / \mathrm{mg} \mathrm{min}$ & $\mathrm{q}, \mathrm{mg} / \mathrm{g}$ & $\mathrm{R}^{2}$ \\
\hline $\mathrm{K}$ & $6.51 \times 10^{-3}$ & 1.84 & 0.56 & $5.11 \times 10^{-2}$ & 4.16 & 0.99 \\
\hline $\mathrm{K}-$ HIS & $9.49 \times 10^{-3}$ & 1.96 & 0.80 & $3.46 \times 10^{-2}$ & 4.46 & 0.98 \\
\hline $\mathrm{K}-\mathrm{CIS}$ & $5.60 \times 10^{-3}$ & 1.60 & 0.50 & $6.76 \times 10^{-2}$ & 4.29 & 0.99 \\
\hline
\end{tabular}

\subsection{Thermodynamic parameters}

Thermodynamic parameters can be determined using the equilibrium constant $\mathrm{Kc}$, which depends on temperature.

The change in free energy $(\Delta \mathrm{G})$, enthalpy $(\Delta \mathrm{H})$ and entropy $(\Delta \mathrm{S})$ associated to the adsorption process were calculated by using following equations (7), (8), (9):

$$
K_{c}=\frac{c_{0}}{c_{e}}
$$

$$
\Delta G=-R T \ln K_{c}
$$

$$
\ln K_{c}=\frac{\Delta S}{R}-\frac{\Delta H}{R T}
$$

Thermodynamic parameters of the adsorption of cadmium ions onto investigated clays are shown in Table 4 . Gibbs free energy $(\Delta G)$ was calculated using $\operatorname{lnKc}$ values for different temperature. The negative values of $\Delta \mathrm{G}$ and $\Delta \mathrm{H}$ indicated that the sorption is a spontaneous and exothermic process. $\Delta \mathrm{G}$ decreased with the increase of temperature. 
Table 4. Thermodynamics parameters of adsorption of cadmium ions on kaolinite, kaolinite modified with histidine and kaolinite modified with cysteine $(\mathrm{c} 0=50.0 \mathrm{mg} / \mathrm{l})$

\begin{tabular}{|c|c|c|c|c|c|}
\hline Adsorbent & $\mathrm{T}, \mathrm{K}$ & $\mathrm{K}_{\mathrm{c}}$ & $\Delta \mathrm{G}, \mathrm{kJ} / \mathrm{mol}$ & $\Delta \mathrm{H}, \mathrm{kJ} / \mathrm{mol}$ & $\Delta \mathrm{S}, \mathrm{kJ} / \mathrm{mol}$ \\
\hline \multirow{3}{*}{ K } & 298 & 4.6232 & -3.7934 & \multirow[t]{3}{*}{-14.7092} & \multirow[t]{3}{*}{$-3.54 \times 10^{-2}$} \\
\hline & 313 & 5.3583 & -4.3683 & & \\
\hline & 333 & 2.5390 & -2.5796 & & \\
\hline \multirow{3}{*}{ K-HIS } & 298 & 6.1702 & -4.5085 & \multirow[t]{3}{*}{-26.9907} & \multirow[t]{3}{*}{$-7.35 \times 10^{-2}$} \\
\hline & 313 & 7.0212 & -5.0717 & & \\
\hline & 333 & 2.0379 & -1.9709 & & \\
\hline \multirow{3}{*}{ K-CIS } & 298 & 5.8444 & -4.3741 & \multirow[t]{3}{*}{-12.7325} & \multirow[t]{3}{*}{$-2.75 \times 10^{-2}$} \\
\hline & 313 & 5.5031 & -4.4377 & & \\
\hline & 333 & 3.4417 & -3.4219 & & \\
\hline
\end{tabular}

\subsection{Influence of different heavy metals on adsorption}

The adsorption capacity depends on the experimental parameters such as contact time, $\mathrm{pH}$ and initial concentration, as stated above. The comparison of adsorption capacity of different heavy metals (lead $(\mathrm{Pb})$ and zinc $(\mathrm{Zn})$ ) in relation to cadmium (Cd) adsorption capacity onto investigated adsorbents is shown in Figure 6 . The results showed that the adsorption capacity depended on which metal ions were adsorbed. The adsorption of metal decreased as follows $\mathrm{Pb} 2+>\mathrm{Cd} 2+$ $>\mathrm{Zn} 2+$, for all three adsorbents.

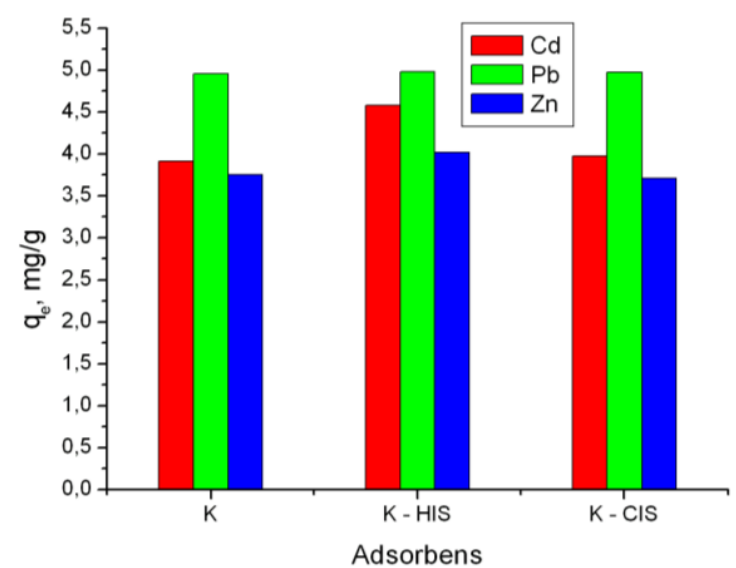

Figure 6 - Adsorption capacity for three different $(\mathrm{Cd}$, $\mathrm{Pb}$ and $\mathrm{Zn}$ ) heavy metals onto all three investigated adsorbents ( $K, K$-HIS and $K$-CIS)

The adsorption capacity of lead ions was high, regardless of the adsorbent being used. The adsorption of cadmium and zinc ions is increased on kaolinite modified with histidine, but remains atthe same level for kaolin modified with cysteine in comparison to raw kaolinite.

\section{CONCLUSION}

The kaolinite modification with amino acids, histidine and cysteine was performed to improve the efficiency of adsorption of cadmium ion. The efficiency of cadmium removal from the aqueous solution onto histidine-modified kaolinite increased from $78.6 \%(\mathrm{~K})$ to $91.8 \%$ (K-HIS). Better agreement with Freundlich's adsorption isotherm and the pseudo-second order kinetics model suggest that the adsorption of cadmium ions on the investigated adsorbents takes place by chemisorption mechanism.

Amino acid (histidine and cysteine) modified kaolinite adsorbents discussed in the present work showed promising results for the separation of $\mathrm{Cd}$ (II) ions from waste water. In order to obtain more precise insight into the adsorption mechanism, the continuation of our research will be directed towards the physicochemical characterization of modified materials, as well as on improving the process of modifying kaolinite with used, but also with some new amino acids.

\section{ACKNOWLEDGMENTS}

The authors are grateful to the Ministry of Education, Science and Technological Development of the Republic of Serbia, Project No. III 45012 and 172007 for financial support. Our special thanks go to Gordana Jelić, Ph.D, a professor of English language, for her support in the translation of this paper.

\section{REFERENCES}

[1] Xu L, Zheng X, Cui H, Zhu Z, Liang J and Zhou J, Equilibrium, Kinetic, and Thermodynamic Studies on the Adsorption of Cadmium from Aqueous Solution by Modified Biomass Ash, Bioinorganic 
Chemistry and Applications, Vol. 2017, pp. 1-9 2017, https://doi.org/10.1155/2017/3695604.

[2] Uddin M. K, A review on the adsorption of heavy metals by clay minerals, with special focus on the past decade, Arabia Chemical Engineering Journal, Vol.308, pp.438-462, 2017.

[3] Mishra S. P, Adsorption-desorption of heavy metal ions, Current Science, Vol. 107 (4), pp.25, 2014.

[4] Bhattacharyya K. G, Gupta S. S, Adsorption of a few heavy metals on natural and modified kaolinite and montmorillonite: A review, Advances in Colloid and Interface Science, Vol.140, pp.114-131, 2008.

[5] Bakatula E. N, Cukrowska E. M, Weiersbye IM, Mihaly-Cozmuta L and Tutu H, Removal of toxic elements from aqueous solution using bentonite modified with L-histidine, Water. Sci. Technol. Vol. 70 (12), pp.2022-2030, 2014.

[6] Danková Z, Bekényiová A, Štyriaková I, Fedorová E, Study of $\mathrm{Cu}(\mathrm{II})$ adsorption by Siderite and Kaolin, Procedia Earth and Planetary Science, Vol.15, pp.821-826, 2015.

[7] Bergaya F, Lagaly G, Handbook of Clay Science, UK, Elsevier, 2003.

[8] Fernandes A. C, Pinto M. L, Antunes F, Pires J, Lhistidine-based organoclays for the storage and release of therapeutic nitric oxide, Journal of Materials Chemistry B, Vol.3, pp. 3556-3563, 2015.

[9] Juźków J, Clay materials modified with amino acids for purification processes of biogas and natural gas, Thesis to obtain the Master of Science Degree in Chemical Engineering, Tecnico Lisboa, 2016.

[10]Varga G, The structure of kaolinite and metakaolinite, Éptőanyag-Journal of the Scientific Society of the Silicate Industry, Vol.59, pp.6 - 9, 2007.

[11]Piresa J, Juźków J, Pinto M.L., Amino acid modified montmorillonite clays as sustainable materials for carbon dioxide adsorption and separation, Colloids and Surfaces A, Vol. 544, pp. 105-110, 2018.

[12]Bergaya F, Lagaly G and Vayer M, Cation and Anion Exchange, Chapter 2.11, Developments in Clay Science, Vol. 5, pp. 333-359, 2013.

[13]Gomer J. S, Yopps S. W, Sandoval S. P. and Clark A. E, Copper Exchange Capacity of Clays and Their Potential Effects on In Situ Copper Leaching, United States Depertment of the Interion, Bureau of Mines, Report of Investigations 9393/1992.
[14]Cynthia A. Coles, Raymond N. Yong, Aspects of kaolinite characterization and retention of $\mathrm{Pb}$ and $\mathrm{Cd}$, Applied Clay Science, Vol. 22, pp.39-45, 2002.

[15]Emmanuel I. Unuabonah, Bamidele I. Olu-Owolabi, Abiola N. Oladoja, Augustine E. Ofomaja and Zhang L. Yang, Journal of Soils and Sediments, Vol. 10, pp. 1103-1114, 2010.

[16]Hashemian S and Parsaei Y, Adsorption of 2-picoline and 3-Amino-2-picoline onto Kaolin and Organomodified Kaolin, Oriental Journal Of Chemistry, Vol. 31(1), pp. 177-184, 2015.

[17]Tunney J. J and Detellier C, Chemically modified kaolinite. Grafting of methoxy groups on the interlamellar aluminol surface of kaolinite, Journal of Materials Chemistry, Vol. 6, pp. 1679-1685, 1996.

[18]Tunney J. J. and Detellier C, Interlamellar covalent grafting of organic units on kaolinite, Chemistry of Materials, Vol. 5 (6), pp.747-748, 1993.

[19]Tunney J. J. and Detellier C, Preparation and characterization of Two Distinct Ethylene Glycol Derivatives of Kaolinite, Clays Clay Miner, Vol.42(5), pp.552-560, 1994.

[20]Ilić B. R, Mitrović A. A, Miličić Lj. R, Thermal Treatment Of Kaolin Clay To Obtain Metakaolin, Serbia, Hemijska industrija, Vol.64(4), pp.351-356, 2010.

[21]Mallakpour S. and Dinari M, Preparation and characterization of new organoclays using natural amino acids and Cloisite $\mathrm{Na}+$, Applied Clay Science, Vol.51, pp.353-359, 2011.

[22]H. de Paiva, L. B, Morales A. R, Valenzuela Diaz F. $\mathrm{R}$, Organoclays: Properties, prepara-tion and applications. Applied Clay Science, Vol.42, pp.8-24, 2008.

[23]Faghihian H, Nejati-Yazdinejad M, Sorption performance of cysteine modified bentonite in heavy metals uptake, Journal of the Serbian Chemical Society, Vol.74(7), pp. 833-843, 2009.

[24]A. I. G. Lima, S. I. Almeida Pereira, E. M. de Almeida Paula Figueira, G. CardosoNunes Caldeira, H.D. Quinteira de Matos Caldeira, Cadmium detoxification in roots of Pisum sativum seedlings: relationship between toxicity levels, thiol pool alterations and growth, Environmental and Experimental Botany, Vol.55(1-2), pp.149-162, 2006.

[25]G. N. Babu, R. Ranjani, G. Fareeda, S. D. S. Murthy, Heavy metal binding polypeptides in plants and their role in metal detoxification, Journal of Phytological Research, Vol.20 (1), pp.1-6, 2007. 
[26]Parsons J. G, Dokken K. M, Mc Clure J, GardeaTorresdey JL, FTIR, XAS, and XRD study of cadmium complexes with L-cysteine, Polyhedron, Vol. 56, pp.237-242, 2013.

[27]Miyoshi Y, Tsukimura K, Morimoto K, Suzuki M, Takagi T, Comparison of methylene blue adsorption on bentonite measured using the spot and colorimetric methods, Applied Clay Science, Vol.151, pp.140-147, 2018.

[28]Kollar T, PalinkoI, Konya Z, Kiricsi I, Intercalating amino acid guests into montmorillonite host, Journal of Molecular Structure, Vol. 651-653, pp. 335-340, 2003.

[29]Dashman T and Stotzky G, Adsorption and binding of Amino Acids on Homoionic Montmorillonite and kaolinite, Soil Biology and Biochemistry, Vol. 14, pp. 447-456, 1982.

[30]Ma C, Eggleton R. A, Cation exchange capacity of kaolinite, Clays and Clay Minerals, Vol.47(2), pp. 174-180, 1999.

[31]Petra L, Billik P, Komadel P, Preparation and characterization of hybrid materials consisting of high- energy ground montmorillonite and $\alpha$-amino acids, Applied Clay Science, Vol.115, pp. 174-178, 2015.

[32]McMurry J, Organic Chemistry, Chapter 26, Biomolecules: Amino Acids, Peptides, and Proteins, 6th Ed. 2003, Roland Kluger, Department of Chemistry, University of Toronto.

[33]Ramos M. E, Huertas F. J, Adsorption of glycine on montmorillonite in aqueous solutions, Applied Clay Science, Vol. 80-81, pp.10-17, 2013.

[34]Bottari E, Festa MR, On the behaviour of cysteine as ligand of cadmium (II), Talanta, Vol.44, pp.1705 1718, 1997.

[35]Benincasa E, Brigatti MF , Malferrari D, Medici L, Poppi L, Sorption kinetics and chemical forms of Cd(II) sorbed by amino acid cysteine exchanged 2:1 clay minerals, Applied Clay Science, Vol.21, pp. $191-201,2002$

[36]El Ass K, Adsorption of cadmium and copper onto natural clay: isotherm, kinetic and thermodynamic studies, Global NEST Journal, Vol.20 (2) pp. 198$207,2018$.

\section{REZIME}

\section{ADSORPCIJA KADMIJUMOVIH JONA NA KAOLINITU MODIFIKOVANIM HISTIDINOM I CISTEINOM}

Kontinualan razvoj novih tehnologija dovodi do povećanog zagađenja vode, čime se stvara potreba za novim materijalima koji se mogu koristiti u procesima prečišćavanja. Kao potencijalni, istražuju se adsorbenti pripremljeni od poljoprivrednog otpada, smola, silika gela, zeolita, gline, letećeg pepela, aluminosilikata i drugih materijala. Nedavna istraživanja su se fokusirala na poboljšanje adsorpcionog kapaciteta modifikovanjem materijala vezivanjem ili impregnacijom neorganskih i organskih molekula na površini. U ovom radu izvršena je modifikacija kaolinita aminokiselinama, histidinom i cisteinom, kako bi se poboljšala efikasnost adsorpcije jona kadmijuma. Kapacitet izmene katjona (CEC) sirovog $i$ modifikovanog kaolinita određen je titracijom sa metilenskim plavim. Ispitivan je uticaj radnih parametara, kao što su vreme adsorpcije, pH vrednost rastvora, početna koncentracija metala, $i$ temperatura, na kapacitet $i$ efikasnost adsorpcije. Bolje slaganje eksperimentalnih rezultata sa Freundlich-ovom adsorpcionom izotermom i kinetičkim modelom pseudo-drugog reda sugeriše da se adsorpcija kadmijumovih jona na ispitivanim adsorbentima odvija putem hemisorpcionog mehanizma. Promena Gibsove slobodne energije ima negativnu vrednost za oba adsorbenta, što pokazuje da je proces adsorpcije spontan. Efikasnost uklanjanja kadmijuma iz vodenog rastvora na kaolinitu modifikovanim histidinom povećava se sa 78,6\% na 91,8\%.

Ključne reči: adsorpcija, kadmijum, aminokiseline, kapacitet katjonske izmene, kaolinit 